\title{
Gramella gaetbulicola sp. nov., a member of the family Flavobacteriaceae isolated from foreshore soil
}

Correspondence Seung Bum Kim sbk01@cnu.ac.kr

\author{
Sung-Heun Cho, ${ }^{1}$ Song-Hee Chae, ${ }^{1}$ Myoungho Cho, ${ }^{1}$ Tae-Ui Kim, ${ }^{1}$ \\ Seri Choi, ${ }^{1}$ Ji-Hye Han, ${ }^{1}$ Young Tae Kim, ${ }^{1}$ Yochan Joung, ${ }^{2}$ Kiseong Joh, ${ }^{2}$ \\ Olga I. Nedashkovskaya ${ }^{3}$ and Seung Bum Kim ${ }^{1}$
}

\author{
${ }^{1}$ Department of Microbiology and Molecular Biology, School of Bioscience and Biotechnology, \\ Chungnam National University, 220 Gung-dong, Yuseong, Daejeon 305-764, Republic of Korea \\ ${ }^{2}$ Department of Bioscience and Biotechnology, Hankuk University of Foreign Studies, \\ San 89 Wangsan-ri, Cheoin, Yongin, Gyeonggi 449-791, Republic of Korea \\ ${ }^{3}$ Pacific Institute of Bioorganic Chemistry of the Far-Eastern Branch of the Russian Academy of \\ Sciences, Prospekt 100 Let Vladivostoku 159, Vladivostok 690022, Russia
}

\begin{abstract}
A Gram-reaction-negative, yellow-pigmented, gliding, rod-shaped, aerobic bacterium (RA5-111 ${ }^{\top}$ ) was isolated from foreshore soil. The taxonomic status of the novel isolate was determined using a polyphasic approach. On the basis of $16 \mathrm{~S}$ rRNA gene sequence similarities, strain RA5-111 ${ }^{\top}$ could be assigned to the genus Gramella, with sequence similarities of $97.7,97.3$ and $96.2 \%$ to the type strains of Gramella echinicola, Gramella portivictoriae and Gramella marina, respectively. Chemotaxonomic and phenotypic characteristics also supported the affiliation of strain RA5-111 ${ }^{\top}$ with the genus Gramella. The genomic DNA G + C content was $39.1 \mathrm{~mol} \%$. The isolate contained MK-6 as the predominant menaquinone, iso- $\mathrm{C}_{15: 0}$, iso- $\mathrm{C}_{17: 0} 3-\mathrm{OH}$ and a summed feature (iso- $\mathrm{C}_{15: 0} 2-\mathrm{OH}$ and/or $\mathrm{C}_{16: 1} \omega 7 \mathrm{c}$ ) as major fatty acids, and phosphatidylethanolamine and unknown phospholipids as the polar lipids. DNA-DNA relatedness, phenotypic, genotypic and chemotaxonomic data clearly indicate that the isolate represents a novel species of the genus Gramella, for which the name Gramella gaetbulicola sp. nov. is proposed. The type strain is RA5- $111^{\top}\left(=\right.$ KCTC $23022^{\top}=$ JCM $16528^{\top}=$ NBRC $\left.106272^{\top}\right)$.
\end{abstract}

The genus Gramella, which belongs to the family Flavobacteriaceae, was first described by Nedashkovskaya et al. (2005) and, at the time of writing, comprised three species: Gramella echinicola (Nedashkovskaya et al., 2005), Gramella portivictoriae (Lau et al., 2005) and Gramella marina (Nedashkovskaya et al., 2010), all of which were found in marine environments. G. echinicola and G. marina were isolated from the sea urchin Strongylocentrotus intermedius (Nedashkovskaya et al., 2005, 2010), whereas G. portivictoriae was isolated from marine sediment (Lau et al., 2005). Eilers et al. (2001) reported that species of the genus Gramella are commonly found in surface seawater. The whole genome of 'Gramella forsetii', a representative member of the former study, was determined and the organism had interesting features showing it to be a welladapted inhabitant of the marine environment (Bauer et al., 2006).

Abbreviation: PE, phosphatidylethanolamine.

The GenBank/EMBL/DDBJ accession number for the 16S rRNA gene sequence of RA5- $111^{\top}$ is G0857650.
In the present study, the taxonomic status of a novel member of the genus Gramella, isolated during a study of halophilic bacterial diversity associated with marine environments, was determined using a polyphasic approach.

Strain RA5-111 ${ }^{\mathrm{T}}$ was isolated from foreshore soil in the Buan area, Jeonbuk, Republic of Korea. The soil sample was suspended in Ringer's solution $(2.25 \mathrm{~g} \mathrm{NaCl}, 0.105 \mathrm{~g}$ $\mathrm{KCl}, 0.12 \mathrm{~g} \mathrm{CaCl}_{2}$ and $0.05 \mathrm{~g} \mathrm{NaHCO}_{3}$ per litre distilled water), serially diluted and spread on marine agar 2216 (Difco). The strain was maintained using the same medium and also as a suspension in $20 \%(\mathrm{w} / \mathrm{v})$ glycerol at $-70{ }^{\circ} \mathrm{C}$.

The Gram-stain reaction was determined using a nonstaining method as described by Buck (1982). Cell morphology was observed with a light microscope (Olympus) using cells grown for $48 \mathrm{~h}$ at $30{ }^{\circ} \mathrm{C}$. Other phenotypic characteristics, including gliding motility, catalase and oxidase activities, and hydrolysis of casein, cellulose, DNA, starch, Tweens 20, 40, 60 and 80, and urea, were ascertained using methods described by Nedashkovskaya et al. (2005) and Cho et al. (2010). Marine broth (Difco) 
was used for determination of growth at 4, 10, 20, 25, 30, 37 and $42{ }^{\circ} \mathrm{C}$ and at $\mathrm{pH} 4-12$ (intervals of $1 \mathrm{pH}$ unit) adjusted with $1 \mathrm{M} \mathrm{HCl}$ or $\mathrm{NaOH}$. Growth in the presence of $0,3,5,10,15$ and $20 \%(\mathrm{w} / \mathrm{v}) \mathrm{NaCl}$ was investigated using a basal medium consisting of $10 \mathrm{~g}$ peptone and 5 g yeast extract per litre distilled water. API 20E, API 20 NE and API ZYM strips (bioMérieux) and GN2 MicroPlates (Biolog) were used to determine other biochemical and physiological properties according to the manufacturers' instructions. The isoprenoid quinone composition was analysed using reversed-phase HPLC as described by Cho et al. (2010). For fatty acid methyl ester analysis, strain RA5-111 ${ }^{\mathrm{T}}$ and the three reference strains were grown on marine agar at $30{ }^{\circ} \mathrm{C}$ for 2 days and fatty acid methyl esters were extracted and prepared according to the standard protocol of the Sherlock Microbial Identification System (MIDI). Polar lipids were determined using two-dimensional TLC followed by spraying with the appropriate detection reagents (Minnikin et al., 1984; Komagata \& Suzuki, 1987). The genomic DNA $\mathrm{G}+\mathrm{C}$ content was determined according to Cui et al. (2007).

The 16S rRNA gene of RA5- $111^{\mathrm{T}}$ was amplified by PCR from chromosomal DNA and sequenced as described previously (Cho et al., 2008). The sequence was aligned together with corresponding sequences of representative species of the genus Gramella using the program PHYDIT version 3.1

Table 1. Phenotypic characteristics differentiating strain RA5-111 ${ }^{\top}$ from type strains of related species of the genus Gramella

Strains: 1, RA5-111 ${ }^{\mathrm{T}}$; 2, G. echinicola KCTC $12278^{\mathrm{T}}$; 3, G. marina KCTC $12366^{\mathrm{T}}$; 4, G. portivictoriae KCTC $22434^{\mathrm{T}}$. All data were obtained from this study except for data obtained with the Biolog GN2 system for G. marina KCTC $12366^{\mathrm{T}}$ (Nedashkovskaya et al., 2010). All taxa were positive for the following: respiratory metabolism, gliding motility, oxidase and catalase activities, hydrolysis of DNA, gelatin, starch, and Tweens 20, 40, 60 and 80, and presence of acid phosphatase, alkaline phosphatase, $\alpha$-chymotrypsin, cystine arylamidase, leucine arylamidase, valine arylamidase, esterase (C4), esterase lipase (C8), $\alpha$ - and $\beta$-glucosidase, trypsin and naphthol-AS-BI-phosphohydrolase. All taxa were negative for the following: nitrate reduction, hydrogen sulfide and indole production, hydrolysis of casein and cellulose, presence of $\alpha$-fucosidase, $\beta$-glucuronidase and urease activities, and acid production from rhamnose, inositol, mannitol and sorbitol.

\begin{tabular}{|c|c|c|c|c|}
\hline Characteristic & 1 & 2 & 3 & 4 \\
\hline Temperature $\left({ }^{\circ} \mathrm{C}\right)$ & $4-42(30-37)$ & $4-42(25)$ & $4-42(25)$ & $4-42(25)$ \\
\hline $\mathrm{NaCl}(\%)$ & $3-10(3-5)$ & $0-15(0-3)$ & $0-15(3-5)$ & $0-5(0-3)$ \\
\hline \multicolumn{5}{|l|}{ Activity of: } \\
\hline Lipase (C14) & - & + & + & + \\
\hline$N$-Acetyl- $\beta$-glucosaminidase & + & + & - & - \\
\hline$\alpha$-Mannosidase & - & - & + & - \\
\hline \multicolumn{5}{|l|}{ Utilization of (Biolog GN2): } \\
\hline $\begin{array}{l}\alpha \text {-Cyclodextrin, dextrin, D-galactose, raffinose, pyruvic acid methyl ester, } \\
\text { succinic acid monomethyl ester, D-gluconic acid, succinic acid, } \\
\text { glycyl-L-glutamic acid, L-leucine, L-threonine, uridine, thymidine, } \\
\alpha \text {-D-glucose } 1 \text {-phosphate }\end{array}$ & + & - & - & - \\
\hline $\begin{array}{l}N \text {-Acetyl-D-galactosamine, inositol, lactulose, L-rhamnose, malonic acid, } \\
\text { quinic acid, D-saccharic acid, glucuronamide, L-alaninamide, hydroxy- } \\
\text { L-proline, urocanic acid, putrescine, glycerol, DL- } \alpha \text {-glycerol phosphate }\end{array}$ & - & - & - & + \\
\hline $\begin{array}{l}\text { i-Erythritol, methyl } \beta \text {-D-glucoside, xylitol, citric acid, D-galactonic acid } \\
\text { lactone, D-glucuronic acid, } \beta \text {-hydroxybutyric acid, itaconic acid, } \\
\text { D-alanine, L-asparagine, D-serine, L-serine, DL-carnitine }\end{array}$ & - & + & - & - \\
\hline $\begin{array}{l}\text { D-Fructose, gentiobiose, } \alpha \text {-ketovaleric acid, succinamic acid, } \\
\text { D-glucose 6-phosphate }\end{array}$ & + & - & - & + \\
\hline D-Mannitol, D-sorbitol, L-aspartic acid & - & + & - & + \\
\hline Sucrose & + & - & + & - \\
\hline D-Galacturonic acid, L-alanyl-glycine & - & + & + & - \\
\hline
\end{tabular}


(http://plaza.snu.ac.kr/ jchun/phydit). Phylogenetic trees were reconstructed on the basis of the Fitch-Margoliash, maximum-likelihood, maximum-parsimony and neighbourjoining algorithms following previously described procedures (Kim et al., 2003). Levels of DNA-DNA relatedness were determined using photobiotin-labelled DNA probes and microdilution wells as described previously (Ezaki et al., 1989). DNA-DNA relatedness data were obtained from experiments carried out in triplicate and reciprocal hybridization reactions.

Strain RA5- $111^{\mathrm{T}}$ formed yellow-orange, circular, convex colonies with entire margins on marine agar at $30{ }^{\circ} \mathrm{C}$ within $48 \mathrm{~h}$. Growth occurred at $4-42{ }^{\circ} \mathrm{C}$ (optimum 30 $37^{\circ} \mathrm{C}$ ) and in 3-10\% (w/v) $\mathrm{NaCl}$ (optimum 3-5\% NaCl). Cells were Gram-reaction-negative, strictly aerobic, nonspore-forming and rod-shaped with gliding ability. Other phenotypic characteristics are given in the species description and Table 1.

Table 2. Fatty acid contents of strain RA5-111 ${ }^{\top}$ and type strains of species of the genus Gramella

Strains: 1, RA5-111 ${ }^{\mathrm{T}}$; 2, G. echinicola KCTC $12278^{\mathrm{T}}$; 3, G. marina KCTC $12366^{\mathrm{T}} ; 4$, G. portivictoriae KCTC $22434^{\mathrm{T}}$. - , not detected or $>1.0 \%$ of total fatty acids.

\begin{tabular}{|c|c|c|c|c|}
\hline Fatty acid & 1 & 2 & 3 & 4 \\
\hline \multicolumn{5}{|l|}{ Straight-chain } \\
\hline $\mathrm{C}_{15: 0}$ & - & - & 3.9 & - \\
\hline$C_{16: 0}$ & 5.8 & 6.9 & - & 4.4 \\
\hline $\mathrm{C}_{18: 0}$ & 3.7 & - & - & - \\
\hline \multicolumn{5}{|c|}{ Branched saturated acids } \\
\hline iso- $\mathrm{C}_{14: 0}$ & - & 1.8 & - & 1.5 \\
\hline iso- $\mathrm{C}_{15: 0}$ & 21.4 & 14.9 & 17.9 & 19.7 \\
\hline anteiso- $\mathrm{C}_{15: 0}$ & 4.0 & 7.8 & 8.6 & 9.1 \\
\hline iso- $\mathrm{C}_{16: 0}$ & 1.5 & 5.3 & 6.3 & 4.3 \\
\hline iso- $\mathrm{C}_{16: 1}$ & - & - & 2.7 & - \\
\hline anteiso- $\mathrm{C}_{16: 0}$ & 1.3 & - & - & - \\
\hline iso- $\mathrm{C}_{17: 0}$ & 1.5 & - & - & - \\
\hline anteiso- $\mathrm{C}_{17: 1} \omega 9 c$ & - & - & 2.2 & 2.7 \\
\hline \multicolumn{5}{|l|}{ Unsaturated acids: } \\
\hline $\mathrm{C}_{15: 1} \omega 6 c$ & - & 1.4 & 1.1 & 1.2 \\
\hline $\mathrm{C}_{17: 1} \omega 6 c$ & - & - & 3.6 & - \\
\hline $\mathrm{C}_{18: 1} \omega 9 c$ & 1.7 & - & - & - \\
\hline \multicolumn{5}{|c|}{ Branched unsaturated acids: } \\
\hline iso- $\mathrm{C}_{15: 0} 3-\mathrm{OH}$ & 3.2 & 2.0 & 1.5 & 2.0 \\
\hline $\mathrm{C}_{15: 0} 2-\mathrm{OH}$ & 1.5 & 2.7 & 2.8 & 3.4 \\
\hline iso- $\mathrm{C}_{16: 0} 3-\mathrm{OH}$ & 2.6 & 8.1 & 3.9 & 4.5 \\
\hline iso- $\mathrm{C}_{17: 0} 3-\mathrm{OH}$ & 22.5 & 20.0 & 12.4 & 15.9 \\
\hline $\mathrm{C}_{17: 0} 2-\mathrm{OH}$ & 3.8 & - & 5.1 & 6.4 \\
\hline iso- $\mathrm{C}_{17: 1} \omega 9 c$ & 5.7 & 2.9 & 5.5 & 4.0 \\
\hline Summed feature ${ }^{\star}$ & 16.7 & 20.5 & 11.6 & 13.0 \\
\hline
\end{tabular}

* Summed features are groups of two or three fatty acids that cannot be separated by GLC using the MIDI system, here, comprising $\mathrm{C}_{16: 1} \omega 7 c$ and/or iso- $\mathrm{C}_{15: 0} 2-\mathrm{OH}$.
MK-6 was found to be the predominant isoprenoid quinone. The strain contained iso- $\mathrm{C}_{15: 0}(21.4 \%)$, iso- $\mathrm{C}_{17: 0} 3-\mathrm{OH}$ $(22.5 \%)$ and a summed feature consisting of iso- $\mathrm{C}_{15: 0} 2-\mathrm{OH}$ and/or $\mathrm{C}_{16: 1} \omega 7 c(16.7 \%)$ as the predominant fatty acids. Table 2 shows the detailed fatty acid profile of strain RA5$111^{\mathrm{T}}$ and related species. The presence of anteiso- $\mathrm{C}_{16: 0}$ $(1.3 \%)$, iso- $\mathrm{C}_{17: 0}(1.5 \%), \mathrm{C}_{18: 0}(3.7 \%)$ and $\mathrm{C}_{18: 1} \omega 9 \mathrm{c}$ $(1.7 \%)$ was characteristic for strain RA5-111 ${ }^{\mathrm{T}}$. The major polar lipid was phosphatidylethanolamine (PE); unknown aminophospholipids and other unknown polar lipids were also present. The presence of $\mathrm{PE}$ as the major lipid is in line with data reported for members of related genera (Nedashkovskaya et al., 2004, 2006; Lim et al., 2008; Kang \& Lee, 2010). The DNA G + C content of RA5- $111^{\mathrm{T}}$ was $39.1 \mathrm{~mol} \%$, which was close to the range reported for the genus Gramella (40.0-41.1 mol\%).

Phylogenetic analysis based on 16S rRNA gene sequences revealed that strain RA5- $111^{\mathrm{T}}$ is a member of the family Flavobacteriaceae, forming a coherent cluster with species of the genus Gramella (Fig. 1). 16S rRNA sequence similarities between RA5-111 ${ }^{\mathrm{T}}$ and the type strains of $G$. echinicola, G. portivictoriae and G. marina were $97.7 \%$ (31 bp differences out of 1356), 97.3\% (36 bp differences) and $96.2 \%$ (51 bp differences), respectively. The mean DNA-DNA relatedness values between RA5- $111^{\mathrm{T}}$ and the type strains of G. echinicola and G. portivictoriae were $48 \%$ and $47 \%$, respectively, thus confirming that the isolate belongs to a novel taxon in the genus Gramella.

The combined phenotypic, chemotaxonomic and phylogenetic evidence clearly indicates that strain RA5- $111^{\mathrm{T}}$

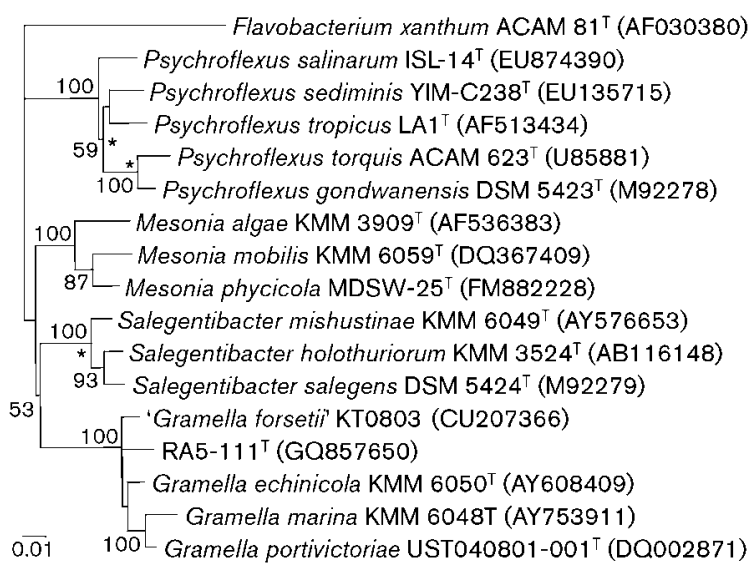

Fig. 1. Neighbour-joining tree based on almost complete $16 \mathrm{~S}$ rRNA gene sequences showing the relationship between strain RA5 $-111^{\top}$ and members of representative species of the genus Gramella. Asterisks indicate branches that were also recovered using the Fitch-Margoliash, maximum-likelihood and maximumparsimony algorithms. Levels of bootstrap support $>50 \%$, based on neighbour-joining analysis of 1000 resampled datasets using Jukes-Cantor distances, are given at branch points. Bar, 0.01 substitutions per nucleotide position. 
represents a novel species of the genus Gramella, for which the name Gramella gaetbulicola sp. nov. is proposed.

\section{Description of Gramella gaetbulicola sp. nov.}

Gramella gaetbulicola (ga.et.bu.li'co.la. N.L. n. gaetbulum gaetbul, the Korean name for a tidal flat; L. suff. -cola from L. masc. or fem. n. incola a dweller, inhabitant; N.L. masc. n. gaetbulicola a dweller of a tidal flat).

Cells are Gram-reaction-negative, strictly aerobic, nonspore-forming, motile by gliding and rod-shaped (1.2$2.7 \times 0.6-0.7 \mu \mathrm{m})$. Colonies are yellow-orange, circular and convex with entire margins on marine agar. Growth occurs at $4-42{ }^{\circ} \mathrm{C}$ (optimum $30-37{ }^{\circ} \mathrm{C}$ ), at $\mathrm{pH} 4-11$ (optimum $\mathrm{pH}$ 7) and in 3-10\% (w/v) $\mathrm{NaCl}$ within 7 days (optimum 3-5\%). Catalase- and oxidase-positive. Acetoin is produced (positive Voges-Proskauer test). Citrate is not utilized. Nitrate and nitrite are not reduced and indole and hydrogen sulfide are not produced. Hydrolyses DNA, starch and Tweens 20, 40, 60 , and 80 , but not casein or cellulose. Acid is not produced from amygdalin, arabinose, glucose, inositol, mannitol, melibiose, rhamnose, sorbitol or sucrose. As determined by API ZYM and API $20 \mathrm{E}$ strips, alkaline and acid phosphatase, esterase (C4), esterase lipase (C8), $\alpha$ - and $\beta$-galactosidase, $\alpha$ and $\beta$-glucosidase, $N$-acetyl- $\beta$-glucosaminidase, leucine arylamidase, valine arylamidase, cystine arylamidase, trypsin, tryptophan deaminase, $\alpha$-chymotrypsin, naphthol-AS-BIphosphohydrolase and gelatinase activities are present, but lipase (C14), $\beta$-glucuronidase, $\alpha$-mannosidase, $\alpha$-fucosidase, arginine dihydrolase, lysine decarboxylase, ornithine decarboxylase and urease activities are absent. Using Biolog GN2 MicroPlates, the following substrates are utilized: $\alpha$-cyclodextrin, dextrin, glycogen, cellobiose, D-fructose, D-galactose, gentiobiose, $\alpha$-D-glucose, maltose, D-psicose, raffinose, sucrose, trehalose, turanose, pyruvic acid methyl ester, succinic acid monomethyl ester, acetic acid, D-gluconic acid, $\alpha$-ketobutyric acid, $\alpha$-ketoglutaric acid, $\alpha$-ketovaleric acid, DL-lactic acid, succinic acid, succinamic acid, L-alanine, Lglutamic acid, glycyl L-aspartic acid, glycyl L-glutamic acid, Lleucine, L-proline, L-threonine, inosine, uridine, thymidine, $\alpha$-D-glucose 1-phosphate and D-glucose 6-phosphate. The predominant menaquinone is MK-6. The major fatty acids are iso- $\mathrm{C}_{15: 0}$, iso- $\mathrm{C}_{17: 0} 3-\mathrm{OH}$ and a summed feature (iso$\mathrm{C}_{15: 0} 2-\mathrm{OH}$ and/or $\mathrm{C}_{16: 1} \omega 7 c$ ). PE, unknown aminophospholipids and other unknown polar lipids are present.

The type strain, RA5-111 ${ }^{\mathrm{T}}\left(=\mathrm{KCTC} 23022^{\mathrm{T}}=\mathrm{JCM} 16528^{\mathrm{T}}\right.$ $=$ NBRC $106272^{\mathrm{T}}$ ), was isolated from the foreshore soil in the Buan area, Jeonbuk, Republic of Korea. The DNA $\mathrm{G}+\mathrm{C}$ content of the type strain is $39.1 \mathrm{~mol} \%$.

\section{Acknowledgements}

This work was supported by the Project on Survey and Excavation of Korean Indigenous Species of the National Institute of Biological Resources (NIBR) under the Ministry of Environment, Korea, and also by the Rural Development Administration, Korea funding the Biogreen 21 program (20080401-034-028-009-02-00).

\section{References}

Bauer, M., Kube, M., Teeling, H., Richter, M., Lombardot, T., Allers, E., Würdemann, C. A., Quast, C., Kuhl, H. \& other authors (2006). Whole genome analysis of the marine Bacteroidetes 'Gramella forsetii' reveals adaptations to degradation of polymeric organic matter. Environ Microbiol 8, 2201-2213.

Buck, J. D. (1982). Nonstaining ( $\mathrm{KOH})$ method for determination of Gram reactions of marine bacteria. Appl Environ Microbiol 44, 992-993.

Cho, S. H., Han, J. H., Ko, H. Y. \& Kim, S. B. (2008). Streptacidiphilus anmyonensis sp. nov., Streptacidiphilus rugosus sp. nov. and Streptacidiphilus melanogenes sp. nov., acidophilic actinobacteria isolated from Pinus soils. Int J Syst Evol Microbiol 58, 1566-1570.

Cho, S. H., Lee, K. S., Shin, D. S., Han, J. H., Park, K. S., Lee, C. H., Park, K. H. \& Kim, S. B. (2010). Four new species of Chryseobacterium from the rhizosphere of coastal sand dune plants, Chryseobacterium elymi sp. nov., Chryseobacterium hagamense sp. nov., Chryseobacterium lathyri sp. nov. and Chryseobacterium rhizosphaerae sp. nov. Syst Appl Microbiol 33, 122-127.

Cui, Y. S., Im, W. T., Yin, C. R., Lee, J. S., Lee, K. C. \& Lee, S. T. (2007). Aeromicrobium panaciterrae sp. nov., isolated from soil of a ginseng field in South Korea. Int J Syst Evol Microbiol 57, 687-691.

Eilers, H., Pernthaler, J., Peplies, J., Glöckner, F. O., Gerdts, G. \& Amann, R. (2001). Isolation of novel pelagic bacteria from the German bight and their seasonal contributions to surface picoplankton. Appl Environ Microbiol 67, 5134-5142.

Ezaki, T., Hashimoto, Y. \& Yabuuchi, E. (1989). Fluorometric deoxyribonucleic acid-deoxyribonucleic acid hybridization in microdilution wells as an alternative to membrane filter hybridization in which radioisotopes are used to determine genetic relatedness among bacterial strains. Int J Syst Bacteriol 39, 224-229.

Kang, H. S. \& Lee, S. D. (2010). Mesonia phycicola sp. nov., isolated from seaweed, and emended description of the genus Mesonia. Int $J$ Syst Evol Microbiol 60, 591-594.

Kim, S. B., Lonsdale, J., Seong, C. N. \& Goodfellow, M. (2003). Streptacidiphilus gen. nov., acidophilic actinomycetes with wall chemotype I and emendation of the family Streptomycetaceae (Waksman and Henrici $(1943)^{\mathrm{AL}}$ ) emend. Rainey et al. 1997. Antonie van Leeuwenhoek 83, 107-116.

Komagata, K. \& Suzuki, K. (1987). Lipid and cell-wall analysis in bacterial systematics. Methods Microbiol 19, 161-207.

Lau, S. C. K., Tsoi, M. M. Y., Li, X., Plakhotnikova, I., Dobretsov, S., Wong, P. K. \& Qian, P. Y. (2005). Gramella portivictoriae sp. nov., a novel member of the family Flavobacteriaceae isolated from marine sediment. Int J Syst Evol Microbiol 55, 2497-2500.

Lim, J. M., Jeon, C. O., Lee, S. S., Park, D. J., Xu, L. H., Jiang, C. L. \& Kim, C. J. (2008). Reclassification of Salegentibacter catena Ying et al. 2007 as Salinimicrobium catena gen. nov., comb. nov. and description of Salinimicrobium xinjiangense sp. nov., a halophilic bacterium isolated from Xinjiang province in China. Int J Syst Evol Microbiol 58, 438-442.

Minnikin, D. E., O'Donnell, A. G., Goodfellow, M., Alderson, G., Athalye, M., Schaal, A. \& Parlett, J. H. (1984). An integrated procedure for the extraction of bacterial isoprenoid quinones and polar lipids. J Microbiol Methods 2, 233-241.

Nedashkovskaya, O. I., Suzuki, M., Vancanneyt, M., Cleenwerck, I., Zhukova, N. V., Vysotskii, M. V., Mikhailov, V. V. \& Swings, J. (2004). Salegentibacter holothuriorum sp. nov., isolated from the edible holothurian Apostichopus japonicus. Int J Syst Evol Microbiol 54, 1107-1110.

Nedashkovskaya, O. I., Kim, S. B., Lysenko, A. M., Frolova, G. M., Mikhailov, V. V., Bae, K. S., Lee, D. H. \& Kim, I. S. (2005). Gramella 
echinicola gen. nov., sp. nov., a novel halophilic bacterium of the family Flavobacteriaceae isolated from the sea urchin Strongylocentrotus intermedius. Int J Syst Evol Microbiol 55, 391-394.

Nedashkovskaya, O. I., Kim, S. B., Zhukova, N. V., Kwak, J., Mikhailov, V. V. \& Bae, K. S. (2006). Mesonia mobilis sp. nov., isolated from seawater, and emended description of the genus Mesonia. Int J Syst Evol Microbiol 56, 2433-2436.

Nedashkovskaya, O. I., Kim, S. B. \& Bae, K. S. (2010). Gramella marina sp. nov., isolated from the sea urchin Strongylocentrotus intermedius. Int J Syst Evol Microbiol 60, 2799-2802. 